\title{
Impacts of vineyard area dynamics on soil erosion in a Mediterranean catchment (1950-2011)
}

\author{
Hari G. Roy, Dennis M. Fox \& Karine Emsellem
}

To cite this article: Hari G. Roy, Dennis M. Fox \& Karine Emsellem (2017): Impacts of vineyard area dynamics on soil erosion in a Mediterranean catchment (1950-2011), Journal of Land Use Science, DOI: 10.1080/1747423X.2017.1385654

To link to this article: http://dx.doi.org/10.1080/1747423X.2017.1385654

$$
\text { 曲 Published online: } 28 \text { Sep } 2017 .
$$

Submit your article to this journal




\title{
Impacts of vineyard area dynamics on soil erosion in a Mediterranean catchment (1950-2011)
}

\author{
Hari G. Roy, Dennis M. Fox and Karine Emsellem \\ UMR 7300 ESPACE CNRS, University Côte d'Azur (UCA), Nice, France
}

\begin{abstract}
The Mediterranean basin has undergone widespread land cover change. Urbanization of coastal areas, land abandonment of steeper slopes, and agricultural intensification in alluvial plains are recurrent themes. The objective of this study was to examine how vineyard land cover changes have affected agricultural soil erosion in a 50 year period (1950-2011). The study area covers a $235 \mathrm{~km}^{2}$ catchment located near the Gulf of St Tropez. Aerial photographs were used to map land cover in 1950, 1982, 2003 and 2011, and the RUSLE soil erosion model was run to estimate soil erosion.

Between 1950 and 2011, vineyard went from about 2,426 ha to 1,561 ha. Mean soil erosion increased as vineyard slopes became steeper (11.8 $\mathrm{T} \mathrm{ha}^{-1}, 13.2 \mathrm{~T} \mathrm{ha}^{-1}, 14.4 \mathrm{~T} \mathrm{ha}^{-1}$ and 13.5 T ha ${ }^{-1}$ for 1950, 1982, 2003 and 2011). Total erosion decreased after 1982: 28,621 $\mathrm{T} \mathrm{y}^{-1}$ in 1950, 29,030 $\mathrm{T} \mathrm{y}^{-1}$ in 1982, 22,848 $\mathrm{T} \mathrm{y}^{-1}$ in 2003, and 21,074 $\mathrm{Ty}^{-1}$ in 2011. Total soil loss in 2011 is about $75 \%$ of values in 1950-1982, so impacts on water pollution and channel dredging have evolved positively over time.
\end{abstract}

\section{ARTICLE HISTORY}

Received 29 May 2017

Accepted 21 September 2017

\section{KEYWORDS}

Land cover change;

Mediterranean; vineyard; soil erosion

\section{Introduction}

Soil is a vital non-renewable resource formed through various physical, chemical, and biological processes in the natural environment, and soil degradation due to erosion has become a serious environmental problem throughout the world (Zika \& Erb, 2009). Soils are under pressure as urban expansion spreads onto fertile land, thereby pushing agricultural activities up onto more marginal and vulnerable soils (Olarieta, Rodriguez-Valle, \& Tello, 2008). Soil erosion risk depends on different topographic, geographic, and climatic conditions, among which land cover, slope, area, soil characteristics, local climatic conditions, and land use management play important roles (Al Kharabsheh, Alexandridis, Bilas, Misopolinos, \& Silleos, 2013). Literature on soil erosion in Mediterranean vineyards has been reviewed extensively by Prosdocimi, Cerdà, and Tarolli (2016), and only a few aspects of this problem are described here.

Vineyard is reported to be one of the land covers most vulnerable to soil loss in the EuroMediterranean region (Cerdan et al. 2010; Kosmas et al., 1997). Mediterranean areas are particularly vulnerable to soil erosion due to high rainfall intensities, agricultural activities on steep slopes, low organic matter, low nutrient contents, and rapid land-use changes (García-Ruiz, 2010; Novara, Gristina, Saladino, \& Cerdà, 2011). García-Ruiz (2010) indicated several reasons for accelerated soil erosion in vineyards: soil is bare during most of the cultivation period and vineyards are relatively common on steeper slopes. Kosmas et al. (1997) also note that many Mediterranean vineyards remain bare and vulnerable to soil loss in spring and summer. Rodrigo Comino et al. (2016) found 
that generally drier conditions and low vegetation cover in Mediterranean vineyards increase erosion. Vineyards in the Mediterranean area have the highest soil erosion rates - greater than rain fed cereals, olives, grassland, and forest cover (Kosmas et al., 1997).

In addition to the direct effects of slope on soil loss, topography is closely related to land cover and soil properties. Slope gradient is a key factor for soil erosion which increases on steeper slopes (El Kateb, Zhang, Zhang, \& Mosandl, 2013; Fox \& Bryan, 2000; Koulouri \& Giourga, 2007; Liu, Dong, $\mathrm{Li}$, \& Zhang, 2013). Therefore, terracing can decrease soil erosion since both gradient and length are reduced (Liu et al., 2013). Van Rompaey, Govers, Van Hecke, and Jacobs (2001) showed that slope played a significant role in arable land and forest conversion during the past 250 years in the Dijle catchment (central Belgium). Arable lands were converted into forest mainly on steeper slopes in 1774-1990, but the reverse occurred on lower slopes. Forest increased on steep slopes and badly drained soils while deforestation took place in relatively flat and favorable loamy soils with well drained areas. García-Ruiz et al. (2010) reviewed the main environmental and human factors affecting soil erosion in the Mediterranean area. According to their study, hydrologic and geomorphologic changes occurred near the Mediterranean coasts of Spain, France, and Italy due to urban sprawl. Urban and suburban pressure near the Mediterranean coast are important and provoke rapid land cover change.

In Southeast France, Roy, Fox, and Emsellem (2014) showed that between 1950 and 2011, vineyard lost more than a third of its initial cover. Urban and suburban encroachment explain much of the loss, but conversion to green space was also important. Vineyard losses in the plain were compensated in part by new fields on steeper slopes. The Giscle river flows into a tourist port located in the Gulf of St Tropez and port authorities have had to dredge the channels to permit navigation.

The objective of this study was to determine the impacts of land cover changes in the Giscle catchment over the 1950-2011 time interval. The study is based on Revised Universal Soil Loss Equation (RUSLE) model predictions for each period. RUSLE evolved from the USLE and is a factorbased model which estimates overall soil erosion rate where each factor quantifies one or more processes and interactions (Millward \& Mersey, 1999; Wischmeier \& Smith, 1978). It estimates soil erosion by considering rainfall, topography, soil, vegetation, land use, and land management (Renard, Foster, Weesies, McCool, \& Yoder, 1997; Zhou, Luukkanen, Tokola, \& Nieminen, 2008). RUSLE has been used extensively throughout the world to predict soil erosion, including in the Mediterranean basin (Guerra, Maes, Geijzendorffer, \& Metzger, 2016). Although more deterministic models are available (eg. WEPP), sufficient data to run these models in the study catchment were not available and RUSLE appears to perform as well or better than WEPP for long term averages (Kinnell, 2017). Land cover trends cited here are comparable to many other Mediterranean locations where near-coastal zones are under intense development pressure (Parras-Alcántara, MartínCarrillo, \& Lozano-García, 2013; Muñoz-Rojas et al., 2015).

\section{Methods}

\subsection{Site description}

The Giscle flows into the Gulf of St Tropez in SE France (Figure 1a) and is described in Fox et al. (2012). It covers about $235 \mathrm{~km}^{2}$ and has a sub-humid Mediterranean climate with a long dry season. Mean annual temperature reaches $27^{\circ} \mathrm{C}$ in summer and $11^{\circ} \mathrm{C}$ in winter, and mean annual rainfall over 1975-2005 was about $895 \mathrm{~mm}$. Peak rainy season is October-December with a second smaller rainy season in April-May. Soils are slightly acidic, stony, and of sandy texture (Fox, Martin, Grosso, \& Morschel, 2006; Roy et al., 2014). Based on 24 wine cooperative soil analyses, soil texture in most of the vineyards is the following: $60-80 \%$ sand, $10-30 \%$ silt and $5-15 \%$ clay.

Grape production is the only farming activity in the catchment. Most of the vineyards in the study area are planted in the slope direction on steeper slopes (except when terraced) and perpendicular to slope at gentler inclinations. Roy et al. (2014) mapped land cover from 


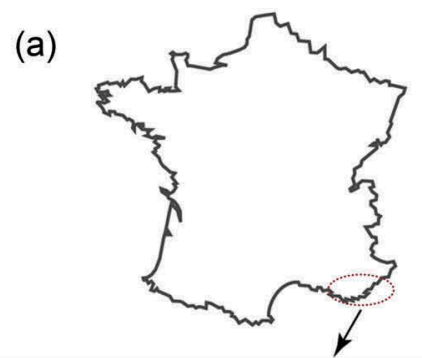

(b)
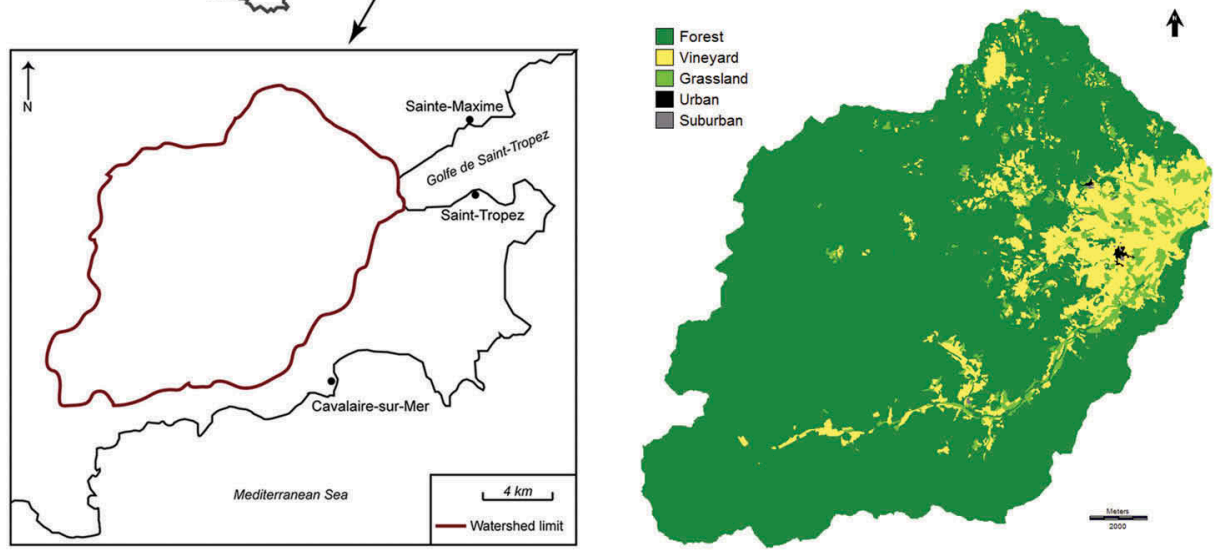

(c)

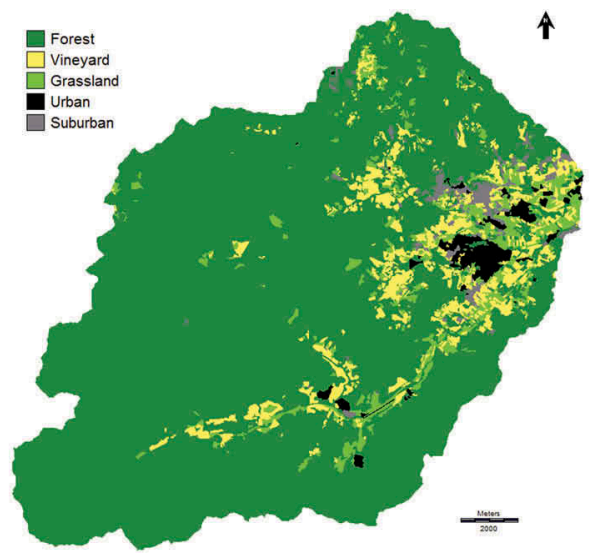

Figure 1. (a)Map showing location of study catchment in SE France. (b) Land cover map of catchment in 1950. (c) Land cover map of catchment in 2001.

orthorectified aerial photographs, and vineyard cover went from about 2,426 ha in 1950 (Figure 1b)

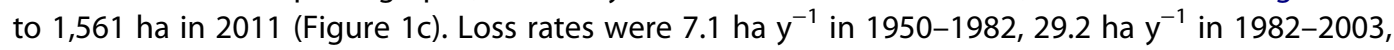
and 3.2 ha $^{-1}$ in 2003-2011. Vineyard fields are located mainly in the sandy floodplain and have spread under urban pressure onto steeper slopes in recent years. Many of the vineyards in the catchment are affected by soil erosion (Figure 2).

\subsection{Erosion estimation using RUSLE}

The RUSLE module in IDRISI estimates average annual soil erosion rates and determines spatial patterns of soil loss (Eastman, 2012; Wischmeier \& Smith, 1978). The model was run using a $25 \mathrm{~m}$ DEM for 1950, 1982, 2003, and 2011 to estimate soil erosion based on land cover maps produced by Roy et al. (2014). RUSLE patch threshold values (described below) were held constant for all 


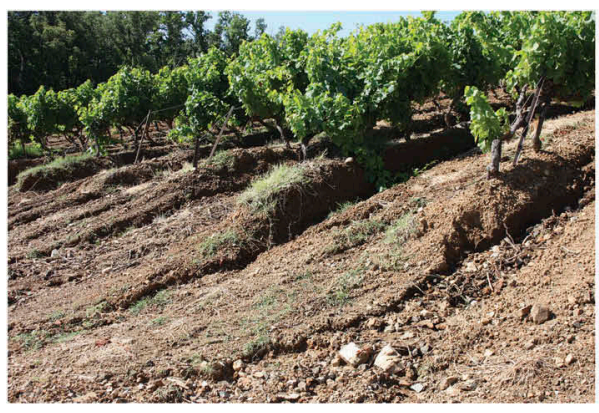

(a)

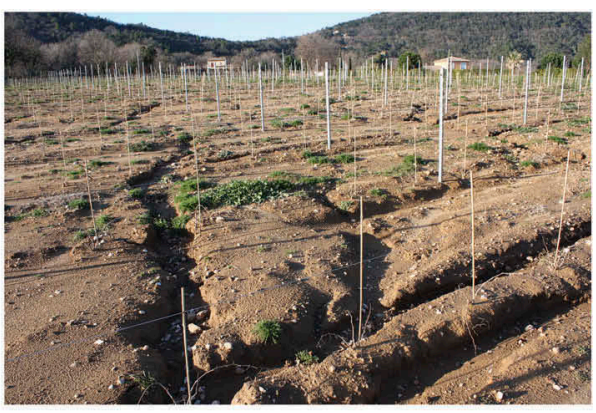

(b)

Figure 2. (a)Soil erosion at end of vineyard rows. (b) Soil erosion in newly planted vineyard.

simulations. RUSLE parameters for erosion estimation are described below and the equation is the following (Renard et al., 1997):

$$
A=R * K * L S * C * P
$$

$\mathrm{A}=$ average annual soil loss $\left(\mathrm{T}_{\text {acre }}^{-1} \mathrm{yr}^{-1}\right)$ (converted to $\mathrm{T} \mathrm{ha} \mathrm{C}^{-1} \mathrm{yr}^{-1}$ )

$\mathrm{R}=$ rainfall-runoff erosivity factor

$\mathrm{K}=$ soil erodibility factor

LS = slope length and gradient factor

$\mathrm{C}=$ cover management factor

$\mathrm{P}=$ support practice factor

All input units for the IDRISI RUSLE module are imperial and the soil loss output $\left(\mathrm{T} \mathrm{acre}^{-1} \mathrm{yr}^{-1}\right)$ is converted to $\mathrm{T} \mathrm{ha}^{-1} \mathrm{yr}^{-1}$ automatically by IDRISI. Methods for calculating each of the parameters are described in detail in Renard et al. (1997) and summarized below.

\subsubsection{Rainfall-runoff erosivity (R)}

In the absence of rainfall intensity data, $R$ was estimated from mean annual rainfall based on daily rainfall recorded in Cogolin (main city in catchment) from 1975 to 2005 (31 years). Torri et al. (2006) calculated $R$ for a nearby region in Tuscany and his equation $(R=-944+3.08 \mathrm{P}$, where $P=$ mean

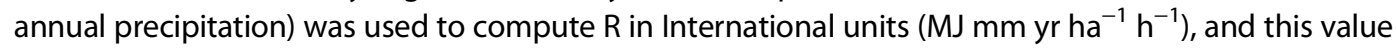
was converted to imperial units (hundreds of foot-ton inches acre ${ }^{-1} \mathrm{~h}^{-1}$ ) based on the method of Cooper (2011). The final $R$ value of 107 was estimated from the average annual rainfall of $895 \mathrm{~mm}$.

\subsubsection{Soil erodibility $(K)$}

A soil map of the watershed was generated from soil data obtained from the local wine-making cooperative. In all, 24 soil samples were obtained, and soil texture was used to estimate $\mathrm{K}$ from the soil erodibility nomograph in Renard et al. (1997: Figure 3-1, p. 92); based on the method of Wischmeier and Smith (1978). A vector point layer was created showing estimated $\mathrm{K}$ values and surface interpolation was applied to create a raster layer for the catchment. $\mathrm{K}$ was expressed in imperial units (tons acre ${ }^{-1}$ per erosion index unit). Greater values of $\mathrm{K}$ indicated lower resistance to soil erosion.

\subsubsection{Topographic factor (LS)}

RUSLE in IDRISI calculates the LS factor automatically from the $25 \mathrm{~m}$ DEM. Slope and aspect thresholds used were $5 \%$ and $180^{\circ}$. Maximum slope length selected was $80 \mathrm{~m}$. The slope and aspect thresholds were used to divide the vineyard surface into homogeneous topographic patches. The smallest patch size selected was $5000 \mathrm{~m}^{2}$. 


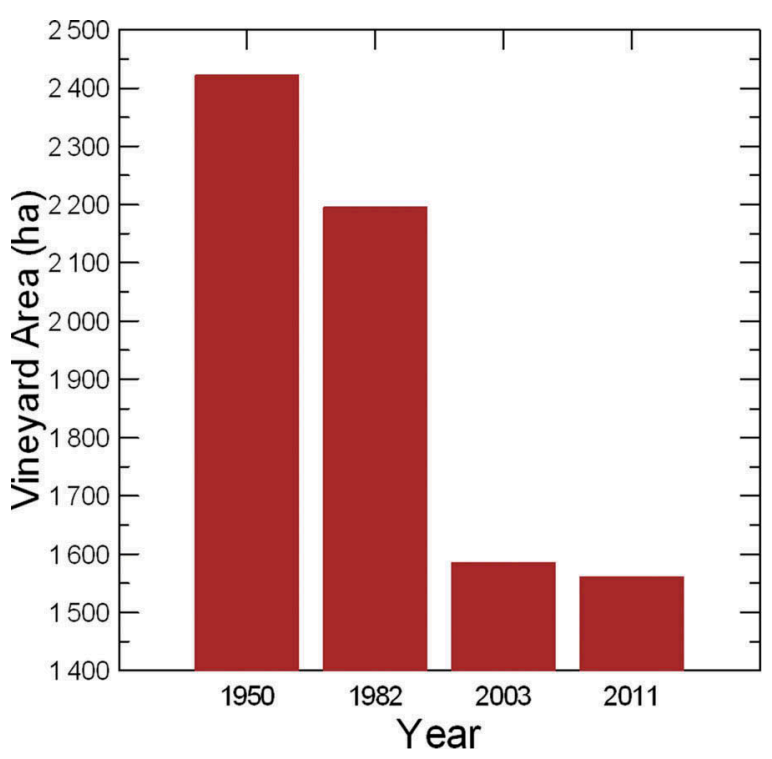

Figure 3. Changes in vineyard area.

\subsubsection{Cover management (C)}

Locally, all interrow vegetation cover is destroyed either mechanically or chemically in the spring to avoid competition for water during the hot dry summer season. In the autumn, grass cover slowly grows back but rates are highly variable from one field to another depending on cultivation technique history. A wide range of $C$ values are therefore possible depending on interrow vegetation characteristics. Since it is impossible to determine these conditions for previous years, $\mathrm{C}$ was estimated at 0.3 for all dates and fields based on observations by Kouli, Soupios, and Vallianatos (2009) and a literature review by Panagos et al. (2015). Although this estimate introduces uncertainties in modeled erosion values (greater erosion for greater $C$ values), it has no implications for the temporal trends of interest here.

\subsubsection{Conservation practice $(P)$}

The alignment of vineyard rows on lower slopes is generally perpendicular to maximum inclination in most of the vineyard fields. This alignment contributes to slow flow velocity, trap sediments, and reduce erosion compared to a bare surface. Therefore, the $P$ value was set at 0.7 for all vineyard surfaces except terraces. From field observations and analysis of aerial photographs, it was noted that terraces are found on most slopes above $10 \%$. Therefore, vineyards at all slopes $\geq 10 \%$ were considered terraced and attributed a $\mathrm{P}$ value of 0.2 .

Soil erosion maps were predicted for 1950, 1982, 2003, and 2011, and erosion values were subsequently simplified into three categories: $<10,10-25$, and $>25 \mathrm{~T} \mathrm{ha}^{-1} \mathrm{y}^{-1}$ as Low, Medium, and High erosion, respectively. These thresholds were selected to compare the 2003 erosion map to measured and extrapolated erosion values by Fox et al. (2006) around the same time. Changes in farming techniques were impossible to account for historically and were ignored.

\section{Results and discussion}

The results are described in the following order: the overall trends in vineyard changes over the study period, soil erosion factors, description of soil erosion in the catchment, and impact of land cover change on soil erosion. 


\subsection{Changes in vineyard area}

A detailed analysis of land cover transitions is available in Roy et al. (2014) and only vineyard changes will be summarized here. Figure 3 shows that total vineyard area declined by about $35 \%$ in 1950-2011 due mainly to urbanization in the plain (Roy et al., 2014). Urban expansion on agricultural farmland is a common trend throughout much of the Mediterranean (Marraccini et al., 2015; Russo, Tomaselli, \& Pappalardo, 2014), and it can be traced back to the $19^{\text {th }}$ century in some areas (Olarieta et al., 2008). Vineyard dropped most in 1982-2003 (by around 30\% of its initial cover), and then it continued to decrease in 2003-2011 but at a much slower rate. Not all the vineyard loss became impervious surfaces as substantial areas were converted to various types of grass or bush land with a high level of swapping between agricultural and natural land covers (conversions in both directions) (Roy et al., 2014). This trend is consistent with the findings of Marraccini et al. (2015) who found that agriculture to natural vegetation swapping increased with proximity to urban centers for 6 Mediterranean cities (4 in the north - France (2), Italy, and Spain; and 2 in the south - Algeria and Morocco), but specific trends with respect to distance from urban center varies from one city to another. Overall, they found that trends are similar for both northern and southern shores for the cities considered, and the major difference was that close to cities, agriculture to natural land dominates in the north while natural to agriculture dominates in the south. This finding is consistent with trends observed here where the dominate transition close to urban centers is vineyard to grassland (Roy et al., 2014).

In addition to urban pressure, the French state undertook several programs of vineyard uprooting premiums ('primes d'arrachage') in order to better control wine production and limit oversupply. In the Var department, where the catchment is located, 1,108 ha, 3,001 ha, and 2,521 ha were uprooted in 1954-1957, 1976-1979, and 1980-1985, respectively, in the context of this national land use policy (Bartoli, 1986).

\subsection{Soil erosion factors}

$\mathrm{R}$ and $\mathrm{C}$ might have varied over time with climate change and agricultural practices, but values were held constant for all dates due to a lack of detailed analyses on these issues. The $\mathrm{K}$ and $\mathrm{P}$ factors for 2011 are presented in Figures 4a and 4b. Most of the soils of the catchment were similar: 22 of 24 soil samples were sandy or very sandy, and $\mathrm{K}$ factor ranged from 0.028 to 0.52 . Mean $\mathrm{K}$ remained constant at 0.33 for all dates. As described by Roy et al. (2014) pressure on the vineyards in the plain led to terracing on steeper slopes as vineyard area in the alluvial plain diminished. $P$ values of 0.2 (terraces) occupied $21.1 \%, 25.3 \%, 28.9 \%$ and $26.1 \%$ of vineyard area in 1950, 1982, 2003, and 2011, respectively. Valle Junior, Varandas, Sanches Fernandes, and Pacheco (2014) noted that terracing was also the dominant form of soil erosion control in the Sordo river basin vineyards, Portugal.

The shift in $\mathrm{P}$ values reflects changes in slope distributions of vineyards over time. Topographic factors will be presented in the form of histograms in original slope length and inclination units to facilitate the comprehension of slope dynamics (Figure 5). Slope inclinations increased from 1950 to 2003 and then decreased slightly in 2011 (Figure 5a). As vineyards occupied steeper slopes, overall slope length (ignoring field boundaries) decreased from close to $200 \mathrm{~m}$ in 1950 to about $120 \mathrm{~m}$ in 2011 (Figure 5b). The range in values remains small for both topographic variables.

\subsection{Soil erosion rates and total erosion}

Mean and median soil erosion rates are presented in Figure 6. Median erosion changes little and mean erosion rates tend to follow slope trends shown in Figure 5a. As steeper slopes were cultivated, mean erosion rate increased (Figure 6) from $11.8 \mathrm{~T} \mathrm{ha}^{-1}$ in 1950 to a maximum of 14.7 $\mathrm{T} \mathrm{ha}^{-1}$ in 2003. Erosion rate values cited are greater than values cited by Cerdan et al. (2010) 


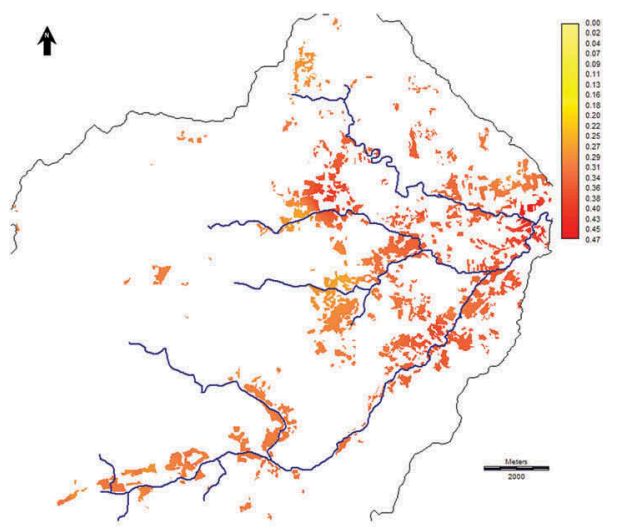

(a)

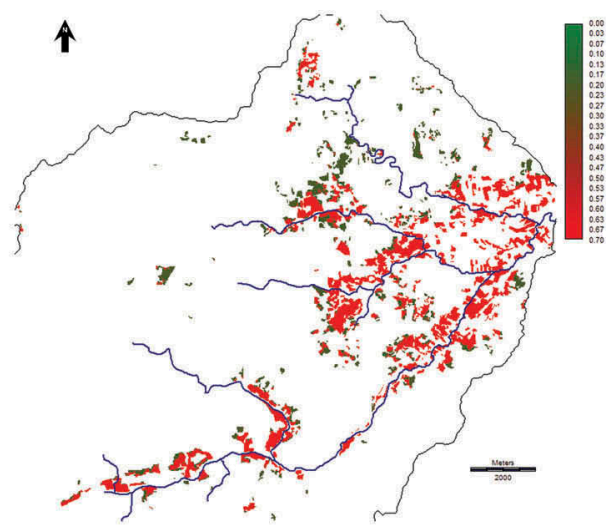

(b)

Figure 4. (a)Map of K-Factor values in vineyards. (b) Map of P-Factor values in vineyards.

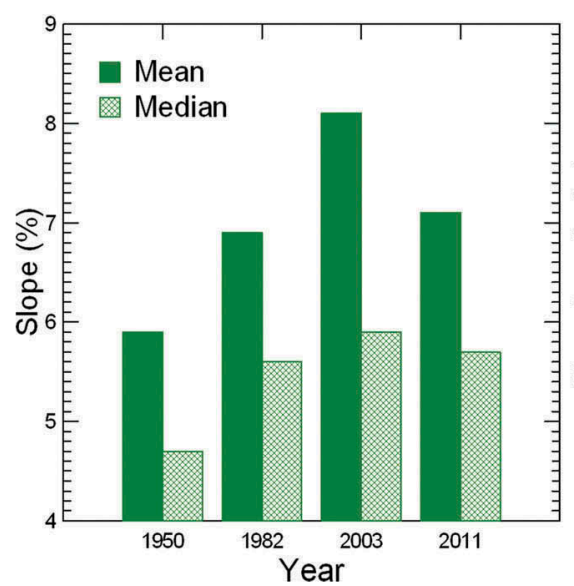

(a)

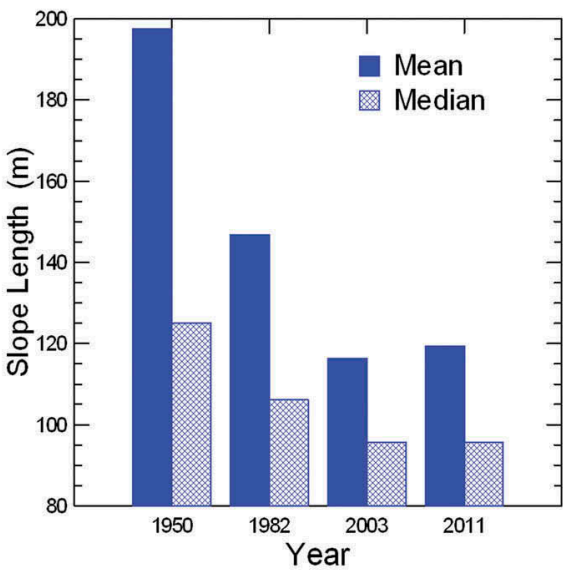

(b)

Figure 5. (a)Changes in mean and median slope inclination over time. b Changes in mean and median slope length over time.

who analyzed soil erosion rates for Mediterranean vineyards and other European crops, and they found mean erosion rates of about $8.6 \mathrm{~T} \mathrm{ha}^{-1} \mathrm{yr}^{-1}$. Raclot et al. (2009) measured erosion rates at the field and catchment scales for tilled and untilled vineyard fields and found erosion rates of ranging from about $0.1 \mathrm{~T} \mathrm{ha}^{-1}$ to $10 \mathrm{~T} \mathrm{ha}^{-1}$ per rainfall event depending on rainfall characteristics and tillage treatment. Quiquerez, Brenot, Garcia, and Petit (2008) summarize mean annual erosion rates for European vineyards from about 17 studies: rates vary widely from $0.32 \mathrm{~T} \mathrm{ha}^{-1}$ to $35 \mathrm{~T} \mathrm{ha}^{-1}$ with a mean of about $11.1 \mathrm{~T} \mathrm{ha}^{-1}$. Since the RUSLE model does not account for sediment deposition, actual erosion rates in this study are probably slightly overestimated.

Total erosion reflects changes in mean erosion rate (Figure 6) and vineyard area (Figure 3); in this study, vineyard area dominates total erosion trends (Figure 7). The small loss in vineyard area between 1950 and 1982 is compensated by an increase in mean erosion rate so the net result is a negligible increase in total erosion (Figure 7). Despite a further increase in mean erosion between 1982 and 2003, total erosion drops by about 21\%. Total erosion decreases again slightly in 2003-2011 as both vineyard area and mean erosion decrease. The changes in total erosion rate correspond to about $-291 \mathrm{~T} \mathrm{y}^{-1}$ and $-224 \mathrm{~T} \mathrm{y}^{-1}$ for the 1982-2003 and 2003-2011 time intervals, 


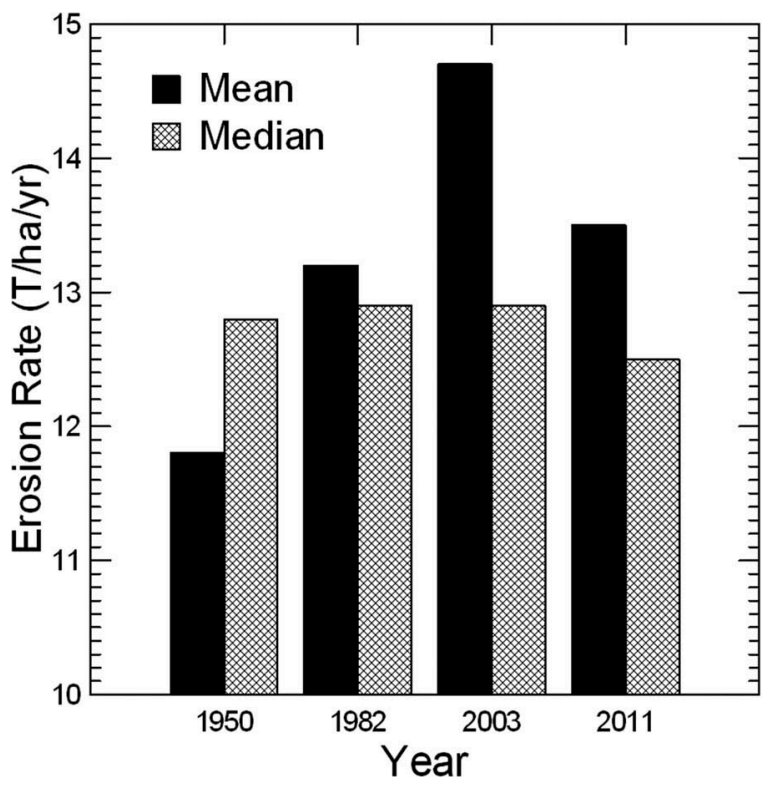

Figure 6. Changes in mean and median soil erosion rates over time.

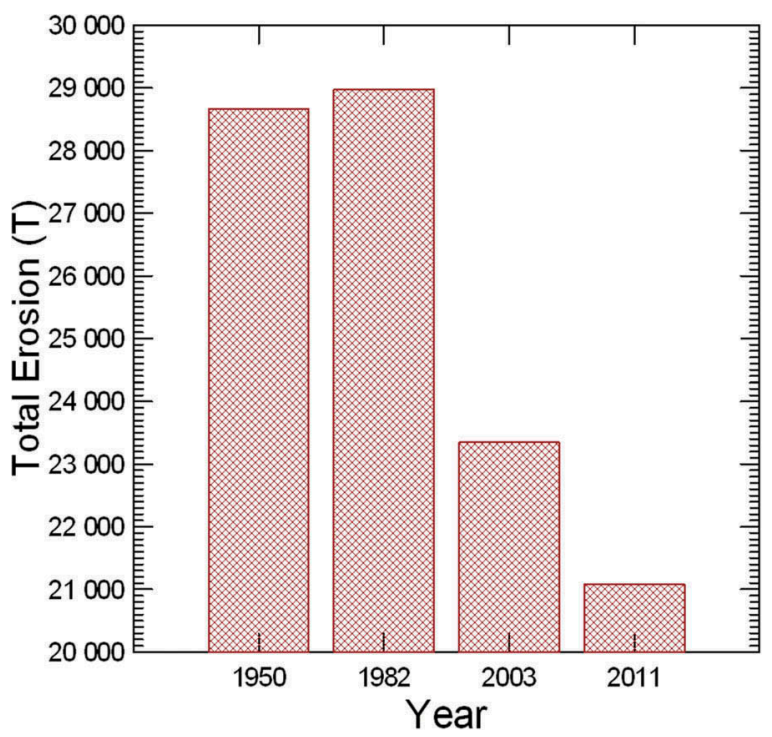

Figure 7. Changes in total soil loss over time.

respectively. Total soil loss corresponds to the mass of sediment that can potentially be injected into the stream network, potentially causing problems for aquatic biodiversity (pesticides and nutrients adsorbed to sediments) and channel navigation in the ports downstream.

Soil erosion categories are mapped in Figure 8. The eastern part remains dominated by Low erosion rates between 1950 and 2011 and is characterized by low slope inclinations and high rates of conversion from vineyard to developed area. Hence, the eroded area shrinks over time (Figure 8a-d). Moderate and High erosion areas also decrease in 1950-2011 but to a lesser extent than the Low erosion category. The Moderate and High erosion areas tend to be 


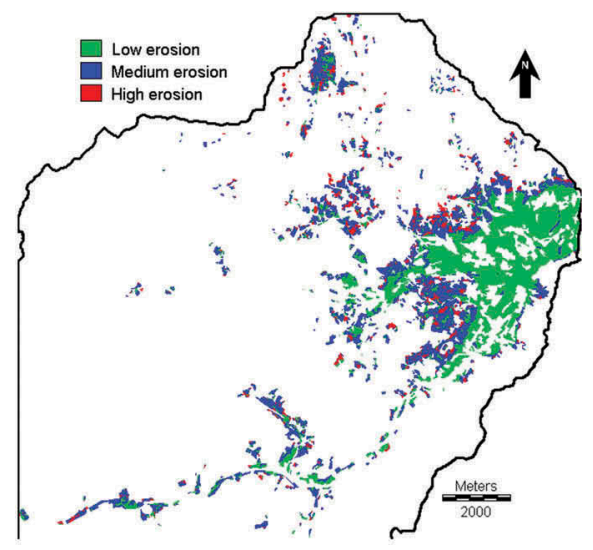

(a)

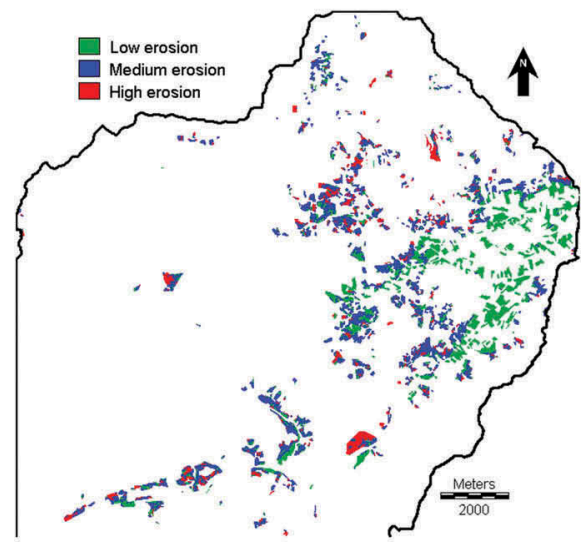

(c)

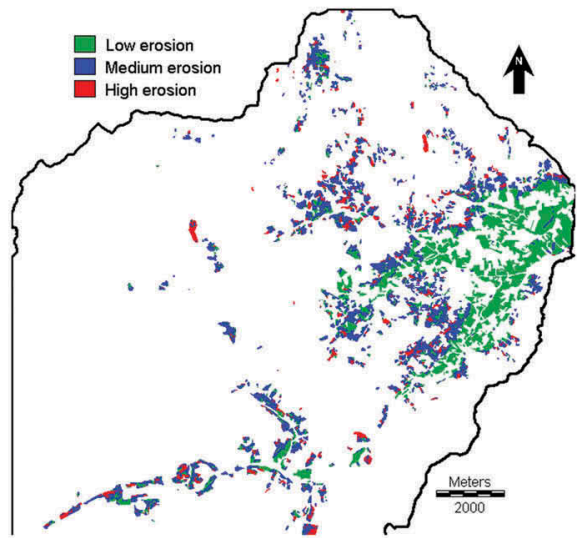

(b)

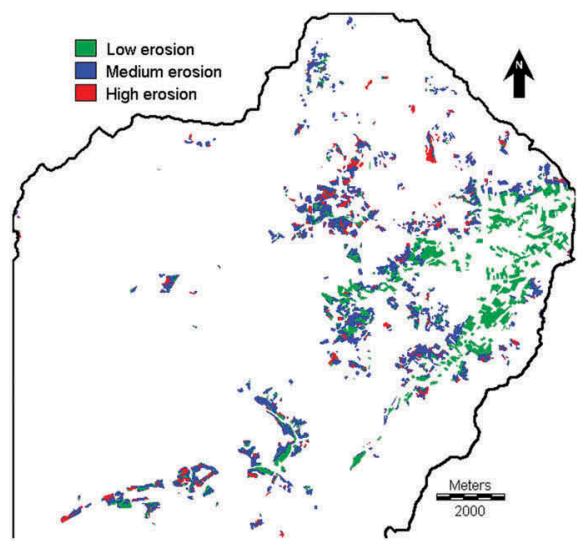

(d)

Figure 8. (a)Soil erosion map for 1950. b Soil erosion map for 1982. (c) Soil erosion map for 2003. (d) Soil erosion map for 2011.

concentrated on the periphery of the alluvial plain. Comparing the 2003 map to values estimated from rill erosion measurements (Fox et al., 2006) indicates that the spatial distribution is good with a small tendency for some fields to be moved from Low to Moderate and Moderate to High erosion categories in the RUSLE simulation, confirming that rates are probably slightly overestimated here.

Traditional vineyard production is a major source of revenue for Mediterranean farmers. However, it contributes to water pollution from pesticides and sediment inputs, so a decrease in vineyard soil erosion is beneficial for both aquatic habitats and groundwater quality. In this case, vineyard area evolved mostly under urban pressure as developed areas encroached onto agricultural land, but part of the loss was the result of deliberate political choices in the state's effort to reduce marginal producers and improve wine quality through uprooting premiums. It is likely that the changes described here led to better vineyard production profit margins (greater value per unit ha) and reduced agricultural water pollution in the 50-year interval (independently of the evolution in pesticides used).

Soil erosion rates increased marginally as fields shifted to steeper slopes, but the overall trend in soil loss was dominated by changes in area. Vineyard lost about 2/3 of its area to Urban and Suburban land covers and about $1 / 3$ to various forms of grass and shrub lands (Roy et al., 2014). The conversion from agricultural to vegetated surfaces helped mitigate the impact of land cover changes on runoff (Fox 
et al., 2012). Most of the vineyard lost was located in the alluvial fan where soils are deeper and more fertile than on bedrock upslope, where new vineyards were implanted. The overall result is a substantial permanent loss in good agricultural land to impervious surfaces and a small, potentially ephemeral, gain in vegetated area (grass and shrub lands). We consider the loss of good farmland a much greater cost than the profit and water quality benefits described above, particularly as these could have been brought about using other strategies (organic farming...). Sustainable land management would require local authorities to develop surrounding hills for urban and suburban land covers and preserve the alluvial plain for agriculture activities rather than the contrary, as was done over the 50-year interval studied here.

\section{Conclusions}

The study quantified the impact of land cover change on soil erosion in vineyards in the Giscle catchment in south-east France where RUSLE was used in the IDRISI GIS environment to create and compare soil erosion rates and maps of 1950, 1982, 2003, and 2011. Public subsidies and urban/ suburban pressure decreased vineyard area by about $30 \%$. Although mean erosion rates increased slightly, the net effect is a decrease in the total sediment loss in the catchment due to the change in vineyard area. The shift of vineyards to steeper slopes is unusual, as most studies observe the abandonment of steeper slopes in favor of more intensive agriculture in alluvial plains. This contradiction is probably only true for vineyards (and not cereal crops). Total erosion in 2011 represents about $75 \%$ of erosion in 1950-1982, and this is probably good news for water quality and port authorities in charge of maintaining navigation channels in the Gulf of St Tropez ports. However, the permanent transformation of fertile soil to impervious surfaces represents a major loss for the catchment.

\section{Acknowlegements}

H. Roy benefitted from a Ph.D. EMMA scholarship for which the authors express their gratitude.

\section{Disclosure statement}

No potential conflict of interest was reported by the authors.

\section{References}

Al Kharabsheh, M.M., Alexandridis, T.K., Bilas, G., Misopolinos, N., \& Silleos, N. (2013). Impact of land cover change on soil erosion hazard in Northern Jordan using remote sensing and GIS. Procedia Environmental Sciences, 19(0), 912921. doi:10.1016/j.proenv.2013.06.101

Bartoli, P. (1986). Les primes à I'arrachage et la regression du vignoble. Une analyse d'impact de la politique viticole. Economie Rurale, 175, 3-19. doi:10.3406/ecoru.1986.3771

Cerdan, O., Govers, G., Le Bissonnais, Y., Van Oost, K., Poesen, J., Saby, N., ... Dostal, T. (2010). Rates and spatial variations of soil erosion in Europe: A study based on erosion plot data. Geomorphology, 122(1-2), $167-177$. doi:10.1016/j.geomorph.2010.06.011

Cooper, K., 2011. Evaluation of the relationship between the RUSLE R-Factor and mean annual precipitation (http:// www.engr.colostate.edu/ pierre/ce_old/Projects/linkfiles/Cooper\%20R-factor-Final.pdf).

Eastman, R. (2012). IDRISI 17: The Selva Edition. Worcester, MA: Clark University.

El Kateb, H., Zhang, H., Zhang, P., \& Mosandl, R.M. (2013). Soil erosion and surface runoff on different vegetation covers and slope gradients: A field experiment in Southern Shaanxi Province, China. Catena, 105(0), 1-10. doi:10.1016/j.catena.2012.12.012

Fox, D.M., \& Bryan, R.B. (2000). The relationship of soil loss by interrill erosion to slope gradient. Catena, 38(3), $211-222$. doi:10.1016/S0341-8162(99)00072-7

Fox, D.M., Martin, C., Grosso, J., \& Morschel, J. (2006). Etude et cartographie de l'érosion des sols dans un vignoble du sud-est de la France. Etudes De Géographie Physique, 33, 23-32. 
Fox, D.M., Witz, E., Blanc, V., Soulié, C., Penalver-Navarro, M., \& Dervieux, A. (2012). A case study of land cover change (1950-2003) and runoff in a Mediterranean catchment. Applied Geography, 32, 810-821. doi:10.1016/j. apgeog.2011.07.007

García-Ruiz, J.M. (2010). The effects of land uses on soil erosion in Spain: A review. Catena, 81(1), 1-11. doi:10.1016/j. catena.2010.01.001

Guerra, C.A., Maes, J., Geijzendorffer, I., \& Metzger, M.J. (2016). An assessment of soil erosion prevention by vegetation in Mediterranean Europe: Current trends of ecosystem service provision. Ecological Indicators, 60, $213-222$. doi:10.1016/j.ecolind.2015.06.043

Kinnell, P.I.A. (2017). A comparison of the abilities of the USLE6M, RUSLE2 and WEPP to model event erosion from bare fallow areas. Science of the Total Environment, 596-597, 32-42. doi:10.1016/j.scitotenv.2017.04.046

Kosmas, C., Danalatos, N., Cammeraat, L.H., Chabart, M., Diamantopoulos, J., Farand, R., ... Vacca, A. (1997). The effect of land use on runoff and soil erosion rates under Mediterranean conditions. Catena, 29(1), 45-59. doi:10.1016/ S0341-8162(96)00062-8

Kouli, M., Soupios, P., \& Vallianatos, F. (2009). Soil erosion prediction using the Revised Universal Soil Loss Equation (RUSLE) in a GIS framework, Chania, Northwestern Crete, Greece. Environmental Geology, 57(3), $483-497$. doi:10.1007/s00254-008-1318-9

Koulouri, M., \& Giourga, C. (2007). Land abandonment and slope gradient as key factors of soil erosion in Mediterranean terraced lands. Catena, 69(3), 274-281. doi:10.1016/j.catena.2006.07.001

Liu, S.L., Dong, Y.H., Li, D., \& Zhang, X.L. (2013). Effects of different terrace protection measures in a sloping land consolidation project targeting soil erosion at the slope scale. Ecological Engineering, 53(0), 46-53. doi:10.1016/j. ecoleng.2012.12.001

Marraccini, E., Debolini, M., Moulery, M., Abrantes, P., Bouchier, A., Chéry, J.-P., ... Napoleone, C. (2015). Common features and different trajectories of land cover changes in six Western Mediterranean urban regions. Applied Geography, 62, 347-356. doi:10.1016/j.apgeog.2015.05.004

Millward, A.A., \& Mersey, J.E. (1999). Adapting the RUSLE to model soil erosion potential in a mountainous tropical watershed. Catena, 38(2), 109-129. doi:10.1016/S0341-8162(99)00067-3

Muñoz-Rojas, M., Jordán, A., Zavala, L.M., De La Rosa, D., Abd-Elmabod, S.K., \& Anaya- Romero, M. (2015). Impact of land use and land cover changes on organic carbon stocks in Mediterranean soils (1956-2007). Land Degrad. Dev., 26, 168-179. doi:10.1002/ldr.2194

Novara, A., Gristina, L., Saladino, S.S., \& Cerdà, A. (2011). Soil erosion assessment on tillage and alternative soil managements in a Sicilian vineyard. Soil and Tillage Research, 117(0), 140-147. doi:10.1016/j.still.2011.09.007

Olarieta, J.R., Rodriguez-Valle, F.L., \& Tello, E. (2008). Preserving and destroying soils, transforming landscapes: Soil and land-use changes in the Vallès County (Catalunya, Spain) 1853-2004. Land Use Policy, 25, 474-484. doi:10.1016/j. landusepol.2007.10.005

Panagos, P., Borrelli, P., Meusburger, K., Alewell, C., Lugato, E., \& Montanarella, L. (2015). Estimating the soil erosion cover-management factor at the European scale. Land Use Policy, 48, 38-50. doi:10.1016/j.landusepol.2015.05.021

Parras-Alcántara, L., Martín-Carrillo, M., \& Lozano-García, B. (2013). Impacts of land use change in soil carbon and nitrogen in a Mediterranean agricultural area (Southern Spain). Solid Earth, 4, 167-177. doi:10.5194/se-4-167-2013

Prosdocimi, M., Cerdà, A., \& Tarolli, P. (2016). Soil water erosion on Mediterranean vineyards: A review. Catena, 141, 121. doi:10.1016/j.catena.2016.02.010

Quiquerez, A., Brenot, J., Garcia, J.-P., \& Petit, C. (2008). Soil degradation caused by a high-intensity rainfall event: Implications for medium-term soil sustainability in Burgundian vineyards. Catena, 73, 89-97. doi:10.1016/j. catena.2007.09.007

Raclot, D., Le Bissonnais, Y., Louchart, X., Andrieux, P., Moussa, R., \& Voltz, M. (2009). Soil tillage and scale effects on erosion from fields to catchment in a Mediterranean vineyard area. Agriculture, Ecosystems, and Environment, 134, 201-210. doi:10.1016/j.agee.2009.06.019

Renard, K.G., Foster, G.R., Weesies, G.A., McCool, D.K., \& Yoder, D.C. (1997). Predicting soil erosion by water: A guide to conservation planning with the revised universal soil loss equation (RUSLE), USDA Agriculture Handbook Number 703.

Rodrigo Comino, J., Iserloh, T., Lassu, T., Cerdà, A., Keestra, S.D., Prosdocimi, M., ... Ries, J.B. (2016). Quantitative comparison of initial soil erosion processes and runoff generation in Spanish and German vineyards. Science of the Total Environment, 565, 1165-1174. doi:10.1016/j.scitotenv.2016.05.163

Roy, H.G., Fox, D.M., \& Emsellem, K. (2014). Spatial dynamics of land cover change in a Euro-Mediterranean catchment (1950-2008). Journal of Land Use Science, 10, 277-297. doi:10.1080/1747423X.2014.898105

Russo, P., Tomaselli, G., \& Pappalardo, G. (2014). Marginal periurban agricultural areas: A support method for landscape planning. Land Use Policy, 41, 97-109. doi:10.1016/j.landusepol.2014.04.017

Torri, D., Borselli, L., Guzzetti, F., Calzolari, C., Bazzoffi, P., Ungaro, F., ... Salvador Sanchis, M.P. (2006). Soil erosion in Italy: An overview. In J. Boardman \& J. Poesen (eds), Soil erosion in Europe (pp. 245-261). New York: Wiley Online Library.

Valle Junior, R.F., Varandas, S.G.P., Sanches Fernandes, L.F., \& Pacheco, F.A.L. (2014). Environmental land use conflicts: A threat to soil conservation. Land Use Policy, 41, 172-185. doi:10.1016/j.landusepol.2014.05.012 
Van Rompaey, A.J.J., Govers, G., Van Hecke, E., \& Jacobs, K. (2001). The impacts of land use policy on the soil erosion risk: A case study in central Belgium. Agriculture, Ecosystems and Environment, 83, 83-94. doi:10.1016/S0167-8809 (00)00173-0

Wischmeier, W.H., \& Smith, D.D. (1978). Predicting rainfall erosion losses: A guide to conservation planning. US. Dep. Agric., Agric. Handb. No. 537, Washington D.C..

Zhou, P., Luukkanen, O., Tokola, T., \& Nieminen, J. (2008). Effect of vegetation cover on soil erosion in a mountainous watershed. Catena, 75(3), 319-325. doi:10.1016/j.catena.2008.07.010

Zika, M., \& Erb, K.-H. (2009). The global loss of net primary production resulting from human-induced soil degradation in drylands. Ecological Economics, 69, 310-318. doi:10.1016/j.ecolecon.2009.06.014 